\title{
Changes of Polyurethane Mechanical Properties Filled with Glass Powder
}

Petr Valášek, Miroslav Müller

Department of Material Science and Manufacturing Technology, Faculty of Engineering, Czech University of Life Sciences in Prague. E-mail: valasekp@tf.czu.cz.

Polyurethanes belong to a wide group of polymers which are applied in many industrial branches. Some polyurethanes can be filled with various types of fillers which optimize their properties for given application. In the paper there are described basic mechanical properties of a constructional two-component polyurethane resin which was filled with microparticles of a glass powder. The aim of the experiment is to define a resulted hardness, a tensile strength and a shear strength of the filled polyurethane resin and set its utility properties further to an application usage of a company PSP Izoterm Ltd. From the measured values $14 \%$ increase of the hardness of the filled systems compared with the unfilled resin is visible, the shear strength of the filled systems did not differ statistically significantly from the unfilled polyurethane, the tensile strength of the polyurethane filled with $5 \%$ of the glass powder was statistically the same with the strength of the unfilled polyurethane.

Keywords: hardness, shear strength, tensile strength

Acknowledgement

Supported by Internal grant agency of Faculty of Engineering, Czech University of Life Sciences in Prague and PSP izoterm

\section{References}

[1] AGARWAL, D., BROUTMAN, J. (1987). Fiber composites, SNTL, 294 p.

[2] BYUNG CHUL KIM, SANG WOOK PARK, DAI GIL LEE. (2008). Fracture toughness of the nano-particle reinforced epoxy composite. Composite Structures, Elsevier, pp. 69 - 77.

[3] SATAPATHY B.K., BIJWE, J. (2002). Analysis of simultaneous influence of operating variables on abrasive wear of phenolic composites. Wear, 253, pp. $787-794$.

[4] DONG CHANG PARK, et al. (2006). Wear characteristics of carbon-phenolic woven composites mixed with nano-parcicles. Composite Structures, 74, pp. 89 - 98.

[5] LIŠKUTIN, P., MAZAL, P., et al. (2011). Modifikace kompozitu Al-Al2O3 malym množstvim Al2O3. Strojirenská technologie, Vol. 4, pp. $41-47$.

[6] KU, H., WONG, P. (2012). Contrast on Tensile and Flexural Properties of Glass Powder Reinforced Epoxy Composites: Pilot Study. Journal of applied polymer science, Vol. 123, pp. $152-161$.

[7] KU, H., TRADA, M., CECIL, T., et al. (2010). Tensile Tests of Phenol Formaldehyde Glass-Powder Reinforced Composites: Pilot Study. Journal of applied polymer science, 116, pp. $10-17$.

[8] VALÁŠEK, P., MÜLLER, M., CHOCHOLOUŠ, P. (2012). Polymerní částicové kompozity na bázi odpadu s obsahem oxidu křemičitého. Strojírenská technologie, Vol. 17, Nr. 1-2, pp. 122 - 127.

[9] MÜLLER, M., VALÁŠEK, P. (2012). Abrasive wear effect on Polyethylene, Polyamide 6 and polymeric particle composites. Manufacturing Technology, Vol. 12, pp. 55 - 59.

[10] MÜLLER, M., VALÁŠEK, P. (2010). Polymerní kompozity na bázi zpevňujících částic odpadů z procesu mechanické povrchové úpravy. Strojírenská technologie, Vol. 14, pp. 183 - 186.

[11] VALÁŠEK, P., MÜLLER, M. (2012). Influence of bonded abrasive particles size on wear of polymeric particle composites based on waste. Manufacturing Technology, Vol. 12, Nr. 13, pp. $268-272$.

[12] KEJVAL, J., MÜLLER, M., HENC, P. (2012). Mechanické vlastnosti a „two-body“ abrazivní opotřebení polymerních částicových kompozitů. Strojirenská technologie, Nr. 1,2, pp. $33-38$.

[13] VALÁŠEK, P., MÜLLER, M. (2012). Polymeric particle composites with filler saturated matrix. Manufacturing Technology, Vol. 12, Nr. 13, pp. $272-276$.

[14] VALÁŠEK, P., MÜLLER, M., PROSHLYAKOV, A. (2012). Effect of sedimentation on the final hardness of polymeric particle composites. Research in Agricultural Engineering, Vol. 58, Nr. 3, pp. 92 - 98. 